\title{
Physiologische Ursachen geistiger Höchstleistungen bei Mann und Weib
}

Von

Dr. M. Vaerting

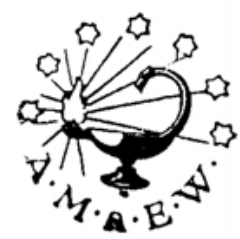

BONN 1922

A. Marcus \& E. Webers Verlag (Dr. jur. Albert Ahn) 